Fetal Diagnosis and Therapy

\title{
Estimation of Detection Rates of Aneuploidy in High-Risk Pregnancy Using an Approach Based on Nuchal Translucency and Non-Invasive Prenatal Testing: A Cohort Study
}

\author{
Asma Khalil ${ }^{a}$ Negar Mahmoodian ${ }^{a}$ Abhijit Kulkarni ${ }^{b}$ Tessa Homfray ${ }^{b}$ \\ Aris Papageorghiou $^{\mathrm{a}}$ Amar Bhide $^{\mathrm{a}}$ Basky Thilaganathan $^{\mathrm{a}}$

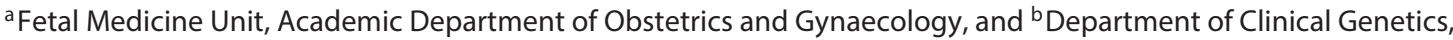 \\ St George's, University of London, London, UK
}

\section{Key Words}

Non-invasive prenatal testing · Karyotype

Nuchal translucency · Prenatal diagnosis · Chorionic villus sampling · Pregnancy

\begin{abstract}
Objectives: The aim was to investigate aneuploidy detection using an approach based on nuchal translucency (NT) and non-invasive prenatal testing (NIPT). Methods: This was a cohort study including 5,306 high-risk pregnancies with NT measurements and chorionic villus samples (CVS) tested for full karyotype. Results: The fetal karyotype was normal in 4,172 (78.6\%) cases and abnormal in 1,134 (21.4\%), including 1,009 with a likely clinically significant adverse outcome. Universal CVS with full karyotyping would lead to the diagnosis of all clinically significant abnormalities. A policy of relying solely on NIPT would have led to the diagnosis of $88.9 \%$ of clinically significant abnormalities. A strategy whereby NIPT is the main method, with CVS reserved for cases with NT $\geq 3.0 \mathrm{~mm}$, would require CVS in $21.7 \%$ of cases, identify $94.8 \%$ of significant abnormalities and avoid miscarriage in 41 pregnancies compared to CVS for all. Conclusions: A policy of NIPT for increased-risk cases and CVS with full karyotype if the NT was $\geq 3.0 \mathrm{~mm}$ reduced the risk of miscarriage yet still identified $95 \%$ of clinically significant aneuploidy.
\end{abstract}

(c) 2015 S. Karger AG, Basel (c) 2015 S. Karger AG, Basel

$1015-3837 / 15 / 0384-0254 \$ 39.50 / 0$

\section{Introduction}

Non-invasive prenatal diagnosis using cell-free fetal DNA in the maternal plasma to determine fetal sex has become a part of routine care in pregnancies at risk of sexlinked disorders [1-3]. Non-invasive prenatal testing (NIPT), using directed cfDNA analysis methods, provides a risk assessment for fetal trisomies 21,18 and 13 [4]. The test requires that the fraction of fetal DNA in the plasma be greater than $4 \%$, which is influenced by maternal and fetal characteristics [5]. There is also an assay failure rate of $1-10 \%$, which increases with the maternal body mass index [5]. NIPT for aneuploidy using cell-free DNA in maternal plasma is increasingly used in clinical practice $[6,7]$. Several studies have reported promising results and some have also included sex chromosome aneuploidy analysis [4, 8-29]. Some have reported correct detection of all trisomy 21 fetuses and $98 \%$ of trisomy 18 cases, with all euploid fetuses correctly identified and a very low $(1 \%)$ assay failure rate $[8,10]$. The use of NIPT as a universal screening tool is unlikely to be cost effective, but its contingent use in women found by conventional screening to be at moderate or high risk has been predicted to be cost effective $[7,30]$. Whether NIPT can replace prenatal invasive testing or whether its use should be limited to selected cases has not been fully elucidated.

\section{KARGER 125}

E-Mail karger@karger.com

www.karger.com/fdt
Dr. Asma Khalil

Fetal Medicine Unit

St George's University of London, Cranmer Terrace

London SW17 0RE (UK)

E-Mail asmakhalil79@googlemail.com 
Increased fetal nuchal translucency (NT) thickness is associated with many chromosomal abnormalities and genetic syndromes [31-34]. Previous studies have demonstrated that the prevalence of chromosomal defects increases with NT thickness [35]. In a study of over 10,000 pregnancies, the prevalence of aneuploidy increased from approximately $7 \%$ in fetuses with NT between the 95th and 99 th centiles for crown-rump length to $75 \%$ for cases with an NT of $8.5 \mathrm{~mm}$ or more [35]. However, half of fetuses with aneuploidy were affected by chromosomal abnormalities other than trisomy 21 [35]. Therefore, firsttrimester screening followed by prenatal invasive testing and full karyotyping allows the detection of a broad range of additional chromosomal abnormalities, many of which may not yet be detectable by NIPT $[35,36]$. Furthermore, the use of microarrays following invasive testing can detect microdeletion syndromes and pathogenic copy number variants associated with a significant risk of physical or mental disability and this is becoming a popular approach [37-39]. In a study of more than 4,000 pregnancies with samples with a normal karyotype, microarray analysis revealed clinically relevant deletions or duplications in $6.0 \%$ of cases with a structural anomaly and in $1.7 \%$ of those whose indications were advanced maternal age or positive screening results [40]. The aim of this study was to investigate the detection rates of clinically significant aneuploidy using an approach based on NT and NIPT.

\section{Methods}

This was a retrospective cohort study including 5,306 high-risk pregnancies from which chorionic villus samples (CVS) had been taken and tested for full karyotype after the fetal NT thickness was measured at $11+0$ to $13+6$ weeks of gestation. Cases were identified by searching the genetic laboratory database and the ViewPoint database (ViewPoint 5.6.8.428; ViewPoint Bildverarbeitung $\mathrm{GmbH}$, Wessling, Germany) at St George's Hospital from January 1997 to January 2013. Data collected included: gestational age at CVS, NT measurement, structural malformations, full karyotype and any further investigations, including amniocentesis, detailed ultrasound, disomy studies, parental karyotyping and pregnancy outcome. The indications for CVS included first-trimester highrisk combined screening results, family history, advanced maternal age, increased NT thickness and fetal structural abnormalities. The karyotypes obtained from cultured chorionic villi were classified as normal or abnormal. All abnormal karyotypes were reviewed by a clinical geneticist and grouped according to whether or not the chromosome anomaly might be clinically significant. Cases with clinically significant chromosomal abnormalities were categorized further into those that would be detected using NIPT and those that would not. Currently NIPT can detect fetuses with trisomy 21, 13 or 18 and sex aneuploidy [5-12]. In a recent study,
Nicolaides et al. [41] reported that cfDNA testing by targeted sequencing and allelic ratio analysis of single-nucleotide polymorphisms covering chromosomes $21,18,13, \mathrm{X}$ and $\mathrm{Y}$ can detect diandric triploidy and raise the suspicion of digynic triploidy. Therefore, we assumed that NIPT is likely to detect, or at least suspect, triploidy and tetraploidy cases as well.

We then examined the distribution of NT thickness in each group and estimated the potential impact, in terms of prenatal diagnosis of clinically significant chromosomal defects, of 3 polices. The first policy reflects the current practice, where all of these cases have a CVS. A second policy would rely entirely on NIPT to replace CVS for all of these high-risk cases. The third policy uses NIPT as the main method of prenatal diagnosis, with CVS followed by full karyotyping reserved for cases with increased NT thickness and a family history of chromsomal abnormalities. We studied the potential impact on the overall miscarriage risk and the cost implications. Assuming a risk of miscarriage associated with CVS of $1 \%$, we calculated the number of miscarriages potentially avoided if NIPT replaced CVS [42-44].

\section{Results}

CVS followed by aneuploidy screening (quantitative fluorescent polymerase chain reaction, qf-PCR) and full karyotype was performed in 5,306 cases. The karyotype was normal in 4,172 (78.6\%) cases and abnormal in 1,134 (21.4\%). The indications of CVS were classified into 5 categories: high-risk screening including those with increased NT with or without biochemistry (44.1\%), structural anomalies (3.5\%), advanced maternal age or anxiety (36.1\%) and family history (16.3\%). We divided the cases with an abnormal karyotype into 1,009 with a high risk of a clinically significant adverse outcome and 125 with no risk or a very low risk of an adverse outcome. Therefore, in total, we had 4,297 cases at no or low risk and 1,009 at high risk for a clinically significant adverse outcome (fig. 1). We further subdivided the group at high risk for a clinically significant adverse outcome into those who would be ( $\mathrm{n}=897 ; 88.9 \%)$ and those who would not be $(\mathrm{n}=112 ; 11.1 \%)$ detected using NIPT. The details of these cases are shown in figure 1.

Table 1 shows the distribution of fetal karyotypes according to fetal NT thickness. A policy of relying entirely on NIPT would lead to the diagnosis of $88.9 \%$ of chromosome abnormalities. An alternative strategy whereby NIPT is the main method of analysis for a high first-trimester risk but with fetal $\mathrm{NT}<3 \mathrm{~mm}$, and CVS with full karyotyping is reserved only for those cases with a minimum fetal NT thickness of $3.0 \mathrm{~mm}$, would require CVS in 1,154 (21.7\%) of cases and would identify 957 (94.8\%) of the significant abnormalities. In this case, the residual risk of an unidentified clinically sig- 
Table 1. Implications of proposed policies in prenatal diagnosis to include CVS only, NIPT only and NIPT with CVS confirmation

\begin{tabular}{|c|c|c|c|c|c|}
\hline Policy of intervention & \multicolumn{2}{|c|}{ Pregnancies at high risk for an adverse outcome } & $\begin{array}{l}\text { Residual risk of an } \\
\text { adverse outcome, } \%\end{array}$ & CVS, $\mathrm{n}^{\mathrm{a}}$ & $\begin{array}{l}\text { Procedure-related } \\
\text { miscarriages, } \mathrm{n}\end{array}$ \\
\hline NIPT in all cases & $897(88.9)$ & $112(11.1)$ & 2.5 & 106 & 1 \\
\hline \multicolumn{6}{|c|}{ CVS (full karyotype) for all above the NT threshold + NIPT for the rest } \\
\hline$\geq 5.5 \mathrm{~mm}$ & $922(91.4)$ & $87(8.6)$ & 2.1 & $535(10.1)$ & 5 \\
\hline$\geq 3.5 \mathrm{~mm}$ & $943(93.5)$ & $66(6.5)$ & 1.5 & $867(16.3)$ & 9 \\
\hline$\geq 3.0 \mathrm{~mm}$ & $957(94.8)$ & $52(5.2)$ & 0.98 & $1,154(21.7)$ & 12 \\
\hline$\geq 2.5 \mathrm{~mm}$ & $963(95.4)$ & $46(4.6)$ & 1.1 & $1,874(35.3)$ & 19 \\
\hline
\end{tabular}

Values are given as numbers (\%) unless otherwise stated. ${ }^{a}$ Without confirming the abnormal NIPT cases.

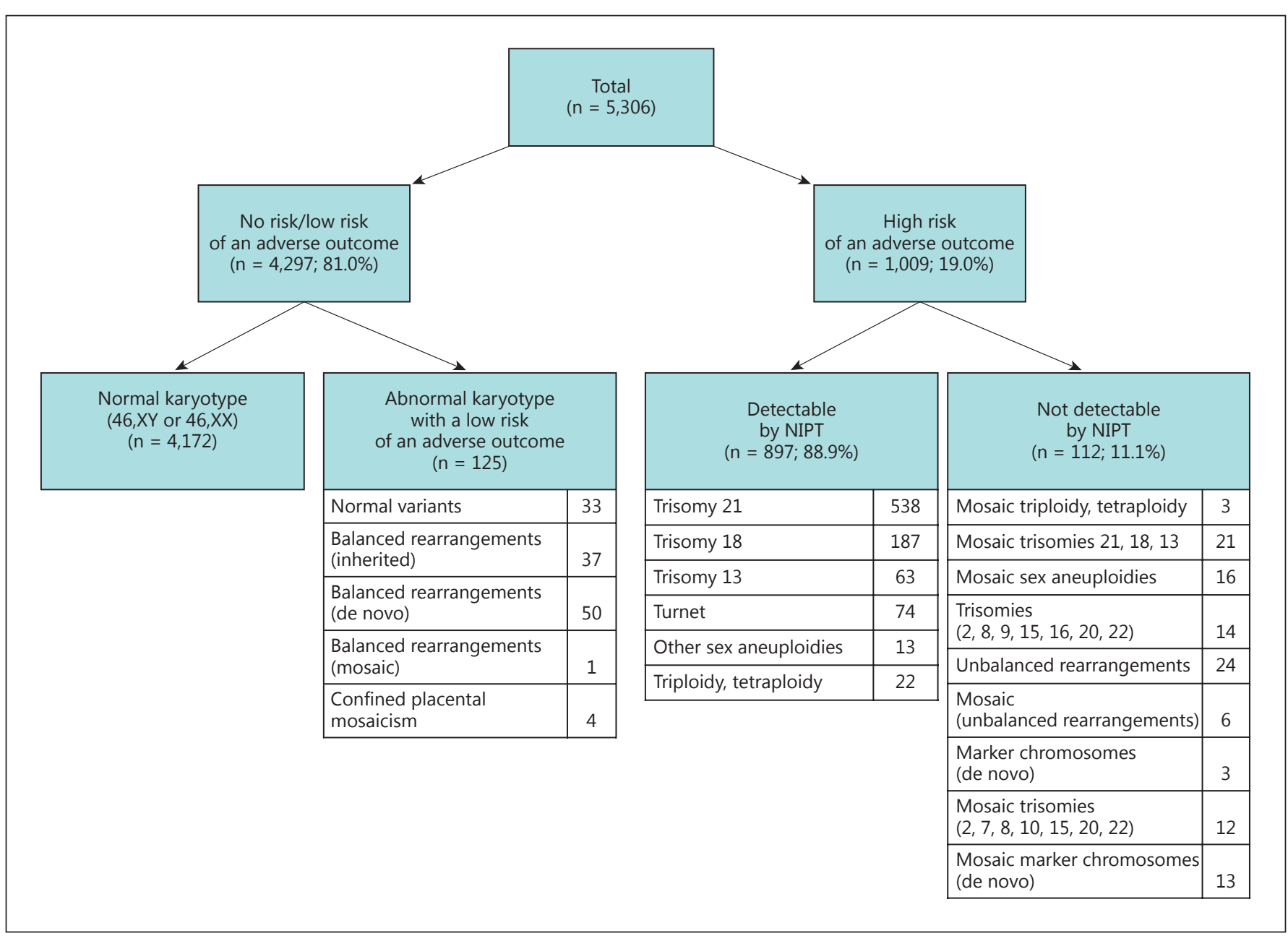

Fig. 1. Fetal karyotype by CVS in the study population showing the likelihood of an adverse postnatal outcome and detection by NIPT, assuming a $0 \%$ failure rate for NIPT. 
Table 2. Fetal aneuploidy of clinical significance not identified by a policy whereby NIPT is the main method of analysis and CVS followed by full karyotyping is reserved for those cases with a minimum fetal NT thickness of $3.0 \mathrm{~mm}$ \begin{tabular}{ll}
\hline Final karyotype after CVS and further investigation & $\begin{array}{l}\text { Total } \\
(\mathrm{n}=52), \\
\mathrm{n}(\%)\end{array}$
\end{tabular}

Mosaic triploidy, tetraploidy

Mosaic trisomies 13, 18 and 21

Mosaic sex aneuploidies

Trisomies 2, 8, 9, 15, 16, 20 and 22

Unbalanced rearrangements

Mosaic unbalanced rearrangements

Mosaic trisomies 2, 7, 8, 10, 15, 20 and 22

Mosaic marker chromosomes (de novo)
$3(5.8)$

$10(19.2)$

$3(5.8)$

$5(9.6)$

$17(32.7)$

$2(3.8)$

$7(13.5)$

$5(9.6)$ nificant karyotype abnormality is $0.98 \%$. The latter policy would avoid miscarriage in $41(78.3 \%)$ pregnancies compared to the current practice of CVS for all. The chromosomal abnormalities of clinical significance that would not have been identified $(\mathrm{n}=52 ; 5.1 \%)$ are listed in table 2 . The largest group was unbalanced rearrangements $(\mathrm{n}=17 ; 32.7 \%)$. In 10 cases there were additional abnormalities that were detected prenatally, which would have triggered further testing. The details of these cases are shown in table 3. A similar strategy with fetal $\mathrm{NT}<3.5 \mathrm{~mm}$ instead would require CVS in 867 (16.3\%) cases and would identify 943 (93.5\%) of the significant abnormalities. In this case the residual risk of an unidentified clinically significant karyotype abnormality is $1.5 \%$. The latter policy would avoid miscarriage in 44 (83.0\%) pregnancies compared to the current practice of CVS for all.

When a policy of CVS with full karyotyping reserved only for those cases with a minimum fetal NT thickness of $3.0 \mathrm{~mm}$, with NIPT for the remaining cases, is compared to the current policy in the UK National Health Service (NHS; CVS followed by full karyotyping for cases with a fetal NT thickness greater than $3.0 \mathrm{~mm}$, while the rest of the cases have qf-PCR), 94.8 versus $96.4 \%$ of the significant abnormalities are likely to be detected ( $\mathrm{p}=$ 0.102 ), while 12 pregnancies (vs. $53, \mathrm{p}<0.001$ ) would be expected to end in miscarriage. A similar number of pregnancies will have CVS followed by karyotype (21.7 vs. $20.1 \%, \mathrm{p}=0.045)$, without confirming the abnormal NIPT cases (table 4).

\section{Discussion}

\section{Main Findings}

We have examined different testing strategies for screen-positive women after first-trimester risk assessment. The findings of this study suggest that a policy of NIPT for first-trimester risk screen-positive women with CVS and karyotyping reserved for those with a minimum fetal NT thickness of $3.0 \mathrm{~mm}$ would require invasive testing in $22 \%$ of cases, identify $95 \%$ of clinically significant abnormalities and avoid the risk of miscarriage in $77 \%$ of pregnancies compared to a policy of CVS for all. The main advantage of this policy compared to the current policy in the UK is a potential reduction in the number of CVS-related miscarriages. This does not seem to be associated with a decrease in the detection of clinically significant chromosomal abnormalities.

\section{Strengths and Limitations}

The strengths of this study include the large number of cases and the ascertainment of the clinical significance of abnormal karyotypes, especially those that might not be detected by NIPT. An attempt to investigate the implications, including the miscarriage risk and the cost, is likely to be important especially in countries where there is a national healthcare system. The limitations of this study include its retrospective design and the fact that it focuses on a high-risk population. The latter issue has been a common limitation in most studies investigating NIPT so far. This study was of all women having CVS for different reasons, reflecting the nature of cases in a tertiary referral centre and not only those at high risk resulting from the routine screening programme. The constitution of this group might limit the generalizability of the findings. We did not include data on the results of the first-trimester screening using the combined test as routine implementation of first trimester serum biochemistry, as part of the combined test, started in 2007. The high chromosomal rate found in our study might skew the analysis. Therefore, we would recommend a similar analysis in a different population to replicate our findings. Furthermore, we assumed that NIPT would detect all cases with trisomy 21, 18, 13, sex aneuploidy, triploidy and tetraploidy, which is unlikely as the detection rate is not $100 \%$. However, as many of these cases, in particular trisomy 18,13 , triploidy and tetraploidy, have structural abnormalities that are easily detected using ultrasound, most of these cases are likely to undergo invasive testing or termination of the pregnancy. 
Table 3. Fetuses with a clinically significant abnormal karyotype, an NT thickness $<3.0 \mathrm{~mm}$ and structural abnormalities $(\mathrm{n}=10)$

\begin{tabular}{lll}
\hline Fetal karyotype & Fetal NT thickness, mm & Fetal abnormalities \\
\hline $46, \mathrm{XX}, \operatorname{rec}(5) \operatorname{dup}(5 \mathrm{q}) \operatorname{inv}(5)(\mathrm{p} 15 \mathrm{q} 35) \mathrm{mat}$ & 1 & small cerebellum \\
$46, \mathrm{XY}, \operatorname{add}(8)(\mathrm{q} 24.3)[4] / 46, \mathrm{XY}[10]$ & 1.3 & bilateral talipes \\
$47, \mathrm{XY},+6$ & 1.3 & Ebstein's anomaly \\
$47, \mathrm{XX},+18[28] / 46, \mathrm{XX}[6]$ & 1.4 & severe fetal growth restriction \\
$46, \mathrm{XX}, \mathrm{t}(5 ; 9)(\mathrm{q} ? 14 ; \mathrm{q} 34), \operatorname{del}(13)(\mathrm{q} 22)[5] / 46, \mathrm{XX}[30]$ & 1.6 & severe fetal growth restriction \\
$\operatorname{mos} 46, \mathrm{XY}[24] / 48, \mathrm{XY},+7,+15[6]$ & 1.6 & hydronephrosis \\
$45, \mathrm{X}[22] / 46, \mathrm{XX}[8]$ & 1.8 & bilateral talipes \\
$92, \mathrm{XXY} / 46, \mathrm{XY}$ & 2.1 & exomphalos \\
$47, \mathrm{XX},+16$ & 2.3 & holoprosencephaly \\
$46, \mathrm{XX}, \operatorname{der}(13) \mathrm{t}(13 ; 18)(\mathrm{q} 32 ; \mathrm{q} 23)$ & 2.6 & \\
\hline
\end{tabular}

Table 4. Implications of proposed policies in prenatal diagnosis to include CVS with qf-PCR only or CVS with full karyotype

\begin{tabular}{|c|c|c|c|c|c|c|}
\hline Policy of intervention & detectable & not detectable & $\begin{array}{l}\text { Residual risk } \\
\text { of an adverse } \\
\text { outcome, } \%\end{array}$ & CVS, n & $\begin{array}{l}\text { Procedure- } \\
\text { related } \\
\text { miscarriages, n }\end{array}$ & $\begin{array}{l}\text { CVS + full } \\
\text { karyotype, } n\end{array}$ \\
\hline CVS + full karyotype & $1,009(100)$ & 0 & 0 & 5,306 & 53 & 5,306 \\
\hline $\mathrm{CVS}+\mathrm{qfPCR}$ in all cases & $934(92.6)$ & $75(7.4)$ & 1.7 & 5,306 & 53 & 0 \\
\hline \multicolumn{7}{|c|}{ CVS (full karyotype) for all above the NT threshold + qf-PCR for the rest } \\
\hline$\geq 3.0 \mathrm{~mm}^{\mathrm{a}}$ & $973(96.4)$ & $36(3.6)$ & 0.8 & 5,306 & 53 & $1,069(20.1)$ \\
\hline$\geq 2.5 \mathrm{~mm}$ & $979(97.0)$ & $30(3.0)$ & 0.7 & 5,306 & 53 & $1,804(34.0)$ \\
\hline
\end{tabular}

Values are given as numbers (\%) unless otherwise stated. ${ }^{\text {a }}$ This is the current policy at the NHS in the UK.

\section{Interpretation}

As NIPT improves, its diagnostic accuracy is likely to improve and more chromosomal abnormalities might be detected, especially with the validation of genomic sequencing from NIPT samples. Furthermore, the role of the first-trimester scan has expanded to include the detection of many fetal structural malformations, which will be followed by CVS and full karyotype, improving the detection rate of atypical chromosomal abnormalities. Despite the promising results of NIPT to date, the assay failure rate remains a limitation, ranging between 0 and $4.9 \%$ [4, $8,10,13,14,17,23,26-28,45]$. The fetal fraction in maternal plasma cfDNA is affected by maternal and fetal characteristics [5]. In a study where the authors extracted cfDNA from the maternal plasma at 11-13 weeks' gestation in 1,949 singleton pregnancies, the fetal fraction decreased with increased maternal weight, advancing gestation and smoking. The estimated proportion with a fetal fraction below $4 \%$, when a reliable result is unlikely to be possible, increased with maternal weight from $0.7 \%$ at 60 $\mathrm{kg}$ to $7.1 \%$ at $100 \mathrm{~kg}$ and $51.1 \%$ at $160 \mathrm{~kg}$ [5].

The key advantage of NIPT is avoiding the risk of miscarriage associated with CVS. In this study we assumed a miscarriage rate of $1 \%$ for CVS; however, this risk might be lower, especially in experienced centres. Furthermore, a recent meta-analysis reported a 5 times lower procedure-related risk of miscarriage (0.2\%) [46]. However, as this was a meta-analysis which included observational studies, and the authors included only studies reporting data on more than 1,000 invasive procedures, the risk of bias including underestimation of the risk of miscarriage should not be ignored. For this reason, we used a miscarriage rate of $1 \%$ in the analysis. Moreover, the risk of miscarriage is likely to differ in low-risk compared to highrisk pregnancies, e.g. those affected by aneuploidy. Of concern is the possibility of false-positive results using 
NIPT, which could occur in cases of confined placental mosaicism $[47,48]$. This has not been demonstrated in studies to date; however, until larger studies in low-risk populations are reported, this risk might remain a concern. So far, pregnant women are advised to confirm a positive (abnormal) NIPT result with invasive prenatal testing to exclude the possibility of a false-positive result.

A prime concern that this study illustrates is the potential failure of NIPT to detect clinically significant aneuploidy that is associated with the risk of physical or mental handicap. However, NIPT technology is likely to be refined to detect other major trisomies. The question remains, though, whether NIPT can detect other chromosomal abnormalities, e.g. mosaicism or unbalanced rearrangement, or whether it would be possible to adapt the technology to perform detailed molecular karyotyping using MLPA or microarray on fetal DNA in the maternal blood. However, we can argue that the screening is offered for Down's syndrome, not other chromosomal abnormalities. Furthermore, failure to detect some of these aneuploidy cases should be weighed against the risk of miscarriage or the anxiety caused by copy number variants of unknown significance, poorly defined penetrance and/or variable expressivity [6]. Future directions might support the option of invasive prenatal diagnosis in cases where the NIPT was normal but the fetus has increased NT or structural abnormalities detected prenatally, as this is the group most likely to have other chromosomal rearrangements $[49,50]$. Chitty et al. [51] reported that MLPA is able to detect $94.7 \%$, compared to $68.4 \%$ by traditional karyotyping, of pathogenic rearrangements conferring a significant risk of adverse outcome. In a meta-analysis comparing array comparative genomic hybridization technology versus conventional karyotyping in prenatal diagnosis, Hillman et al. [52] demonstrated that up to 5\% additional genomic imbalances can be detected using array-comparative genomic hybridization technology in cases where there is a structural malformation on ultrasound.

One disadvantage of NIPT is the 12 days needed for a result (vs. 2-3 for qf-PCR) and the resulting need for medical (vs. surgical) termination in affected cases. It is also expected that, as public knowledge about this test grows, there will be more demand for it by pregnant women, adding to the cost burden. In a recent study involving more than 1,000 women and their partners, Lewis et al. [53] investigated the users' views on NIPT. Interestingly, only $50 \%$ thought that NIPT should be routinely offered to all women, with the remainder favouring contingent NIPT for women at high risk following routine screening [53]. This new technology remains controversial not only among healthcare professionals but also among the public.

\section{Conclusions}

This study suggests that a policy of NIPT in all cases with an increased risk of aneuploidy following first-trimester screening with CVS followed by full karyotype only if the fetal NT thickness is increased would reduce the risk of a procedure-related miscarriage and identify $95 \%$ of clinically significant chromosomal abnormalities.

\section{Disclosure Statement}

B.T. and A.P. are partners at Ultrasound Diagnostic Services, a private women's ultrasound service in London that currently provides both Harmony ${ }^{\mathrm{TM}}$ and NIFTY ${ }^{\mathrm{TM}}$ NIPT at a non-profit cost to clients. A.K. and B.T. are local PIs of a multicentre national study investigating NIPT in the UK (funded by the NIHR). A.P. is the local PI of the IONA study (an NIPT study which is commercially funded).

\section{References}

$\rightarrow$ Bustamante-Aragones A, Rodriguez de Alba M, Gonzalez-Gonzalez C, Trujillo-Tiebas MJ, Diego-Alvarez D, Vallespin E, Plaza J, Ayuso C, Ramos C: Fetal sex determination in maternal blood from the seventh week of gestation and its role in diagnosing hemophilia in the fetuses of female carriers. Haemophilia 2008; 14:593-598.
2 Scheffer PG, van der Schoot CE, Page-Christiaens GC, Bossers B, van Erp F, de Haas M: Reliability of fetal sex determination using maternal plasma. Obstet Gynecol 2010;115: 117-126.

- 3 Hill M, Finning K, Martin P, Hogg J, Meaney C, Norbury G, Daniels G, Chitty LS: Non-invasive prenatal determination of fetal sex: translating research into clinical practice. Clin Genet 2011;80:68-75.
4 Hui L: Non-invasive prenatal testing for fetal aneuploidy: charting the course from clinical validity to clinical utility. Ultrasound Obstet Gynecol 2013;41:2-6.

5 Ashoor G, Syngelaki A, Poon LC, Rezende JC, Nicolaides KH: Fetal fraction in maternal plasma cell-free DNA at 11-13 weeks' gestation: relation to maternal and fetal characteristics. Ultrasound Obstet Gynecol 2013;41: 26-32. 
6 Benn P, Cuckle H, Pergament E: Non-invasive prenatal testing for aneuploidy: current status and future prospects. Ultrasound $\mathrm{Ob}-$ stet Gynecol 2013;42:15-33.

-7 Chitty LS, Hill M, White H, Wright D, Morris S: Non-invasive prenatal testing for aneuploidy-ready for prime time? Am J Obstet Gynecol 2012;206:269-275.

8 Nicolaides KH, Syngelaki A, Ashoor G, Birdir C, Touzet G: Non-invasive prenatal testing for fetal trisomies in a routinely screened firsttrimester population. Am J Obstet Gynecol 2012;207:374.e1-e6.

-9 Ashoor G, Syngelaki A, Wang E, Struble C, Oliphant A, Song K, Nicolaides KH: Trisomy 13 detection in the first trimester of pregnancy using a chromosome-selective cell-free DNA analysis method. Ultrasound Obstet Gynecol 2013;41:21-25.

10 Ashoor G, Syngelaki A, Wagner M, Birdir C, Nicolaides KH: Chromosome-selective sequencing of maternal plasma cell-free DNA for first-trimester detection of trisomy 21 and trisomy 18. Am J Obstet Gynecol 2012;206: 322.e1-e5.

11 Mazloom AR, Džakula Ž, Oeth P, Wang H, Jensen T, Tynan J, McCullough R, Saldivar JS, Ehrich M, van den Boom D, Bombard AT, Maeder M, McLennan G, Meschino W, Palomaki GE, Canick JA, Deciu C: Non-invasive prenatal detection of sex chromosomal aneuploidies by sequencing circulating cell-free DNA from maternal plasma. Prenat Diagn 2013;33:591-597.

-12 Nicolaides KH, Syngelaki A, Gil M, Atanasova $V$, Markova $D$ : Validation of targeted sequencing of single-nucleotide polymorphisms for non-invasive prenatal detection of aneuploidy of chromosomes 13, 18,21, X, and Y. Prenat Diagn 2013;33:575-579.

13 Chiu RW, Akolekar R, Zheng YW, Leung TY, Sun H, Chan KC, Lun FM, Go AT, Lau ET, To WW, Leung WC, Tang RY, Au-Yeung SK, Lam H, Kung YY, Zhang X, van Vugt JM, Minekawa R, Tang MH, Wang J, Oudejans CB, Lau TK, Nicolaides KH, Lo YM: Non-invasive prenatal assessment of trisomy 21 by multiplexed maternal plasma DNA sequencing: large scale validity study. BMJ 2011; 342:c7401.

14 Palomaki GE, Kloza EM, Lambert-Messerlian GM, Haddow JE, Neveux LM, Ehrich M, van den Boom D, Bombard AT, Deciu C, Grody WW, Nelson SF, Canick JA: DNA sequencing of maternal plasma to detect Down syndrome: an international clinical validation study. Genet Med 2011;13:913-920.

15 Verweij EJ, van den Oever JM, de Boer MA, Boon EM, Oepkes D: Diagnostic accuracy of non-invasive detection of fetal trisomy 21 in maternal blood: a systematic review. Fetal Diagn Ther 2012;31:81-86.

16 Dan S, Wang W, Ren J, Li Y, Hu H, Xu Z, Lau TK, Xie J, Zhao W, Huang H, Xie J, Sun L, Zhang X, Wang W, Liao S, Qiang R, Cao J, Zhang Q, Zhou Y, Zhu H, Zhong M, Guo Y, Lin L, Gao Z, Yao H, Zhang H, Zhao L, Jiang
F, Chen F, Jiang H, Li S, Li Y, Wang J, Wang J, Duan T, Su Y, Zhang X: Clinical application of massively parallel sequencing-based prenatal non-invasive fetal trisomy test for trisomies 21 and 18 in 11,105 pregnancies with mixed risk factors. Prenat Diagn 2012;32: 1225-1232.

17 Lo YM, Lun FM, Chan KC, Tsui NB, Chong KC, Lau TK, Leung TY, Zee BC, Cantor CR, Chiu RW: Digital PCR for the molecular detection of fetal chromosomal aneuploidy. Proc Natl Acad Sci USA 2007;104:13116-13121.

18 Fan HC, Blumenfeld YJ, El-Sayed YY, Chueh J, Quake SR: Microfluidic digital PCR enables rapid prenatal diagnosis of fetal aneuploidy. Am J Obstet Gynecol 2009;200:543.e1-e7.

19 Evans MI, Wright DA, Pergament E, Cuckle HS, Nicolaides KH: Digital PCR for non-invasive detection of aneuploidy: power analysis equations for feasibility. Fetal Diagn Ther 2012;31:244-247.

20 Lo YM, Tsui NB, Chiu RW, Lau TK, Leung TN, Heung MM, Gerovassili A, Jin Y, Nicolaides KH, Cantor CR, Ding C: Plasma placental RNA allelic ratio permits non-invasive prenatal chromosomal aneuploidy detection. Nat Med 2007;13:218-223.

21 Go AT, Visser A, van Dijk M, Mulders MA, Eijk P, Ylstra B, Blankenstein MA, van Vugt JM, Oudejans CB: A novel method to identify syncytiotrophoblast-derived RNA products representative of trisomy 21 placental RNA in maternal plasma. Methods Mol Biol 2008; 444:291-302.

22 Chen EZ, Chiu RW, Sun H, Akolekar R, Chan KC, Leung TY, Jiang P, Zheng YW, Lun FM, Chan LY, Jin Y, Go AT, Lau ET, To WW, Leung WC, Tang RY, Au-Yeung SK, Lam H, Kung YY, Zhang X, van Vugt JM, Minekawa $\mathrm{R}$, Tang MH, Wang J, Oudejans CB, Lau TK, Nicolaides KH, Lo YM: Non-invasive prenatal diagnosis of fetal trisomy 18 and trisomy 13 by maternal plasma DNA sequencing. PLoS One 2011;6:e21791.

23 Lau TK, Chen F, Pan X, Pooh RK, Jiang F, Li Y, Jiang H, Li X, Chen S, Zhang X: Non-invasive prenatal diagnosis of common fetal chromosomal aneuploidies by maternal plasma DNA sequencing. J Matern Fetal Neonatal Med 2012;25:1370-1374.

24 Guex N, Iseli C, Syngelaki A, Deluen C, Pescia G, Nicolaides KH, Xenarios I, Conrad B: A robust second-generation genome-wide test for fetal aneuploidy based on shotgun sequencing cell-free DNA in maternal blood. Prenat Diagn 2013;33:707-710.

-25 Ehrich M, Deciu C, Zweifellhofer T, Tynan JA, Cagasan L, Tim R, Lu V, McCullough R, McCarthy E, Nygren AO, Dean J, Tang L, Hutchison D, Lu T, Wang H, Angkachatchai V, Oeth P, Cantor CR, Bombard A, van den Boom D: Non-invasive detection of fetal trisomy 21 by sequencing of DNA in maternal blood: a study in a clinical setting. Am J Obstet Gynecol 2011;204:205.e1-e11.

26 Bianchi DW, Platt LD, Goldberg JD, Abuhamad AZ, Sehnert AJ, Rava RP; MatErnal
BLood IS Source to Accurately diagnose fetal aneuploidy (MELISSA) Study Group: Genome-wide fetal aneuploidy detection by maternal plasma DNA sequencing. Obstet Gynecol 2012;119:890-901.

-27 Sparks AB, Struble CA, Wang ET, Song K, Oliphant A: Non-invasive prenatal detection and selective analysis of cell-free DNA obtained from maternal blood: evaluation for trisomy 21 and trisomy 18. Am J Obstet Gynecol 2012;206:319.e1-e9.

28 Norton ME, Brar H, Weiss J, Karimi A, Laurent LC, Caughey AB, Rodriguez MH, Williams J 3rd, Mitchell ME, Adair CD, Lee H, Jacobsson B, Tomlinson MW, Oepkes D, Hollemon D, Sparks AB, Oliphant A, Song K: Non-Invasive Chromosomal Evaluation (NICE) Study: results of a multicenter prospective cohort study for detection of fetal trisomy 21 and trisomy 18 . Am J Obstet Gynecol 2012;207:137.e1-e8.

29 Palomaki GE, Deciu C, Kloza EM, LambertMesserlian GM, Haddow JE, Neveux LM, Ehrich $\mathrm{M}$, van den Boom D, Bombard AT, Grody WW, Nelson SF, Canick JA: DNA sequencing of maternal plasma reliably identifies trisomy 18 and trisomy 13 as well as Down syndrome: an international collaborative study. Genet Med 2012;14:296-305.

30 Cuckle H, Benn P, Pergament E: Maternal cfDNA screening for Down syndrome - a cost sensitivity analysis. Prenat Diagn 2013;33: 636-642.

31 Nicolaides KH: Nuchal translucency and other first-trimester sonographic markers of chromosomal abnormalities. Am J Obstet Gynecol 2004;191:45-67.

32 Pandya PP, Kondylios A, Hilbert L, Snijders RJM, Nicolaides KH: Chromosomal defects and outcome in 1,015 fetuses with increased nuchal translucency. Ultrasound Obstet Gynecol 1995;5:15-19.

33 Souka AP, Snijders RJ, Novakov A, Soares W, Nicolaides KH: Defects and syndromes in chromosomally normal fetuses with increased nuchal translucency thickness at 10 14 weeks of gestation. Ultrasound Obstet Gynecol 1998;11:391-400.

34 Souka AP, Von Kaisenberg CS, Hyett JA, Sonek JD, Nicolaides KH: Increased nuchal translucency with normal karyotype. Am J Obstet Gynecol 2005;192:1005-1021.

35 Kagan KO, Avgidou K, Molina FS, Gajewska K, Nicolaides KH: Relation between increased fetal nuchal translucency thickness and chromosomal defects. Obstet Gynecol 2006;107: 6-10.

36 Alamillo CM, Krantz D, Evans M, Fiddler M, Pergament E: Nearly a third of abnormalities found after first-trimester screening are different than expected: 10-year experience from a single center. Prenat Diagn 2013;33:251-256.

37 Gruchy N, Decamp M, Richard N, JeannePasquier C, Benoist G, Mittre H, Benoist G, Leporrier N: Array CGH analysis in high risk pregnancies: comparing DNA from cultured cells and cell-free fetal DNA. Prenat Diagn 2011;32:383-388. 
38 Chitty LS, Kistler J, Akolekar R, Liddle S, Nicolaides K, Levett L: Multiplex ligation-dependent probe amplification (MLPA): a reliable alternative for fetal chromosome analysis? J Matern Fetal Neonatal Med 2012;25: 1383-1386.

- 39 Hillman SC, McMullan DJ, Williams D, Maher ER, Kilby MD: Microarray comparative genomic hybridization in prenatal diagnosis: a review. Ultrasound Obstet Gynecol 2012;40: 385-391.

40 Wapner RJ, Martin CL, Levy B, Ballif BC, Eng CM, Zachary JM, Savage M, Platt LD, Saltzman D, Grobman WA, Klugman S, Scholl T, Simpson JL, McCall K, Aggarwal VS, Bunke B, Nahum O, Patel A, Lamb AN, Thom EA, Beaudet AL, Ledbetter DH, Shaffer LG, Jackson L: Chromosomal microarray versus karyotyping for prenatal diagnosis. N Engl J Med 2012;367:2175-2184.

41 Nicolaides KH, Syngelaki A, Del Mar Gil M, Soledad Quezada M, Zinevich Y: Prenatal detection of fetal triploidy from cell-free DNA testing in maternal blood. Fetal Diagn Ther 2014;35:212-217.

42 Royal College of Obstetricians and Gynaecologists: Amniocentesis and Chorionic Villus Sampling - Green-Top Guideline No 8. London, RCOG, 2010.

43 Enzensberger C, Pulvermacher C, Degenhardt J, Kawacki A, Germer U, Gembruch U,
Krapp M, Weichert J, Axt-Fliedner R: Fetal loss rate and associated risk factors after amniocentesis, chorionic villus sampling and fetal blood sampling. Ultraschall Med 2012; 33:E75-E79.

44 Tabor A, Alfirevic Z: Update on procedurerelated risks for prenatal diagnosis techniques. Fetal Diagn Ther 2010;27:1-7.

45 Gil MM, Quezada MS, Bregant B, Ferraro M, Nicolaides KH: Implementation of maternal blood cell-free DNA testing in early screening for aneuploidies. Ultrasound Obstet Gynecol 2013;42:34-40.

46 Akolekar R, Beta J, Picciarelli G, Ogilvie C, D'Antonio F: Procedure-related risk of miscarriage following amniocentesis and chorionic villus sampling: a systematic review and meta-analysis. Ultrasound Obstet Gynecol 2015;45:16-26.

47 Ledbetter DH, Zachary JM, Simpson JL, Golbus MS, Pergament E, Jackson L, Mahoney MJ, Desnick RJ, Schulman J, Copeland KL: Cytogenetic results from the U.S. Collaborative Study on CVS. Prenat Diagn 1992;12: 317-345.

48 Smith K, Lowther G, Maher E, Hourihan T, Wilkinson T, Wolstenholme J: The predictive value of findings of the common aneuploidies, trisomies 13, 18 and 21, and numerical sex chromosome abnormalities at CVS: experience from the ACC U.K. Collaborative
Study. Association of Clinical Cytogeneticists Prenatal Diagnosis Working Party. Prenat Diagn 1999;19:817-826.

49 Kagan KO, Chitty LS, Cicero S, Eleftheriades $\mathrm{M}$, Nicolaides KH: Ultrasound findings before amniocentesis in selecting the method of analyzing the sample. Prenat Diagn 2007;27: 34-39.

50 Chitty LS, Kagan KO, Molina FS, Waters JJ, Nicolaides KH: Fetal nuchal translucency scan and early prenatal diagnosis of chromosomal abnormalities by rapid aneuploidy screening: observational study. BMJ 2006;332:452-455.

51 Chitty LS, Kistler J, Akolekar R, Liddle S, Nicolaides K, Levett L: Multiplex ligation-dependent probe amplification (MLPA): a reliable alternative for fetal chromosome analysis? J Matern Fetal Neonatal Med 2012;25: 1383-1386.

52 Hillman SC, Pretlove S, Coomarasamy A, McMullan DJ, Davison EV, Maher ER, Kilby MD: Additional information from array comparative genomic hybridization technology over conventional karyotyping in prenatal diagnosis: a systematic review and meta-analysis. Ultrasound Obstet Gynecol 2011;37:6-14.

53 Lewis C, Hill M, Silcock C, Daley R, Chitty LS: Non-invasive prenatal testing for Down syndrome: a cross-sectional survey of service user's views and likely uptake. BJOG 2014;121: 582-594. 